\title{
COMPLEMENTARY DESCRIPTION OF THE MIDDLE ORDOVICIAN TRILOBITE ASSOCIATIONS AT PRAHA-VOKOVICE
}

\author{
Martin David $^{1}$ \& Petr Budil ${ }^{2}$
}

${ }^{1}$ Lublaňská 1002/9, 12000 Praha 2, Czech Republic; E-mail: ordovik@seznam.cz

2 Česká geologická služba, Klárov 3, 11821 Praha 1, Czech Republic; E-mail: petr.budil@geology.cz

\begin{abstract}
The temporarily exposed rocks of the Dobrotivá Formation (Middle Ordovician, upper Darriwilian) accessible, due to lower water levels, in Džbán water reservoir (Praha-Vokovice area) have produced common fauna. The newly obtained trilobite-dominated fossil associations enable a more detailed discussion of faunal changes in the lower and lower-middle portions of the Dobrotivá Formation - a transition from the Placoparia Association to the newly recognized Degamella-Zeliszkella Association, dominated by mesopelagic forms.
\end{abstract}

Key words: Ordovician, trilobite associations, Dobrotivá Formation, Praha-Vokovice

\section{INTRODUCTION}

The area around Praha-Vokovice is a part of the long studied classical Barrandian area (see Chlupáč et al. 1999). It has been the subject of paleontological research for almost 150 years. Unfortunately, almost all of the classic paleontologic localities in the Dobrotivá Formation in this region are now inaccessible (Budil 1999a). Summaries of previous investigations of the Dobrotivá Formation in the area can be found in Budil (1999a) and Peršín \& Budil (2005). Most of the classic localities produced fosiliferous nodules collected loose in the fields or from small excavations with only limited stratigraphic data.

The locality on the south bank of Džbán water reservoir in Vokovice is the only area periodically available (in winter, see below). When exposed only the lower to possibly middle portions of the Dobrotivá Formation are accessible; this is the only such locality in the eastern part of the Prague Basin. The locality was first described by Budil (in 1999a). At that time, the outcrop was accessible only in the winter, when water levels were lowered. Between 2006 to 2008, the reservoir was drained, cleaned and reconstructed. During this process all the mud was removed and bottom of the pond became accessible allowing more extensive collecting. The resulting data and collections allow further analysis of the fossil associations.

All specimens discussed herein are deposited either in the collections of the Czech Geological Survey (CGS PB and CGS MS), or in the collec- tions of the National Museum (registered under cumulative number NM 16/92).

\section{Complementary description of the locality}

Budil (1999a) described a simplified stratigraphic section of the outcrop. The outcrop, more than 600 meters in length, exposed a total of $350 \mathrm{~m}$ of strata, characterized by the shale dominant section divided by relatively thin interbeds of quartzose sandstones which divide the section in to six intervals with differing lithologies. The shales are poorly fossiliferous. The rich fauna was collected almost exclusively from the siliceous and silty nodules (Budil 1999a, Peršín \& Budil 2005). Each shale interval contains nodules with a distinctive fauna. Monotonously inclined quartzose sandstones yielded only scarce trace fossils (e.g. Skolithos). The shales are tightly folded and (on the bottom of the reservoir) dip NE between 30$45^{\circ}$, locally also $30-40^{\circ}$ to the SE. A question as to whether a fault displaces the section remains unresolved. No fault has been observed directly and there is no recognized repetition of section at the reservoir, however Peršín \& Budil (2005, p. 31) mentioned finding loose (none were found in situ) nodules typical for the underlying Šárka Formation (lower to middle Darriwilian) in the easternmost part of the outcrop. No stratigraphic contact of both formations was documented at Džbán and a stream transport of nodules by the Šárecký potok Brook could explain their shift as the shales 
of the Šrárka Formation are exposed about $2 \mathrm{~km}$ upstream where the Šárecký potok Brook crosses this formation.

\section{Decription of the section}

The subdivision of the section follows the concept of Budil (1999a). This author subdivided the section at Džbán into the six intervals I-VI (oldest to youngest). The intervals I-II correspond with the lowermost part of the Dobrotivá Formation represented by the Skalka Quartzite Facies (white to brownish quartzose sandstones). Total thickness of interval I (massive sandstones banks) is about $50 \mathrm{~m}$. The thickness of interval II (thin-layered laminated sandstones) is about $8 \mathrm{~m}$. Interval III is a grey silty shales about $40 \mathrm{~m}$ thick and contained rare nodules with a unique fauna. The fauna consists of two taxa, Placoparia (P.) zippei, represented by several cephala and Archaeoconularia insignis by one complete well preserved specimen (CGS PB 1501). Interval IV is a $15 \mathrm{~m}$ thick sequence of platy quartzose sandstones.

The majority of the fauna was collected from Intervals V and VI. Faunal differences in the associations allowed for more precise biostratigraphic subdivisions particularly in V (about $150 \mathrm{~m}$ thick).

Interval V: The lowest part (V.1) is a black clayey shale with dark grey to black, 4 to $10 \mathrm{~cm}$ dia. siliceous nodules containing abundant fossils. Their internal molds are often leached out by water and most of these molds are yellow to orange in color. The fossiliferous nodules are not limited to a single bedding surface but are randomly dispersed within the section. The fauna is dominated by benthic forms. The most common being ubiquitous Placoparia (P.) zippei with tens of minute specimens forming accumulations of entire or almost entire exoskeletons in some nodules (see specimens CGS PB 497-498, NM 16/92). Other species are less frequent but are also represented by complete or slightly disarticulated exoskeletons. Dalmanitid trilobites are represented by Ormathops novaki (NM 16/92) and Zeliszkella oriens, including "morphotype" corresponding to invalid (see Budil 1999b) subspecies of M. Šnajdr (1987) $Z$. o. egesta, the former slightly more numerous than the later. Illaenid trilobites are rare with Ectillaenus benignensis represented by disarticulated cephala and pygidia. Other taxa are represented by single specimens or by single nodules

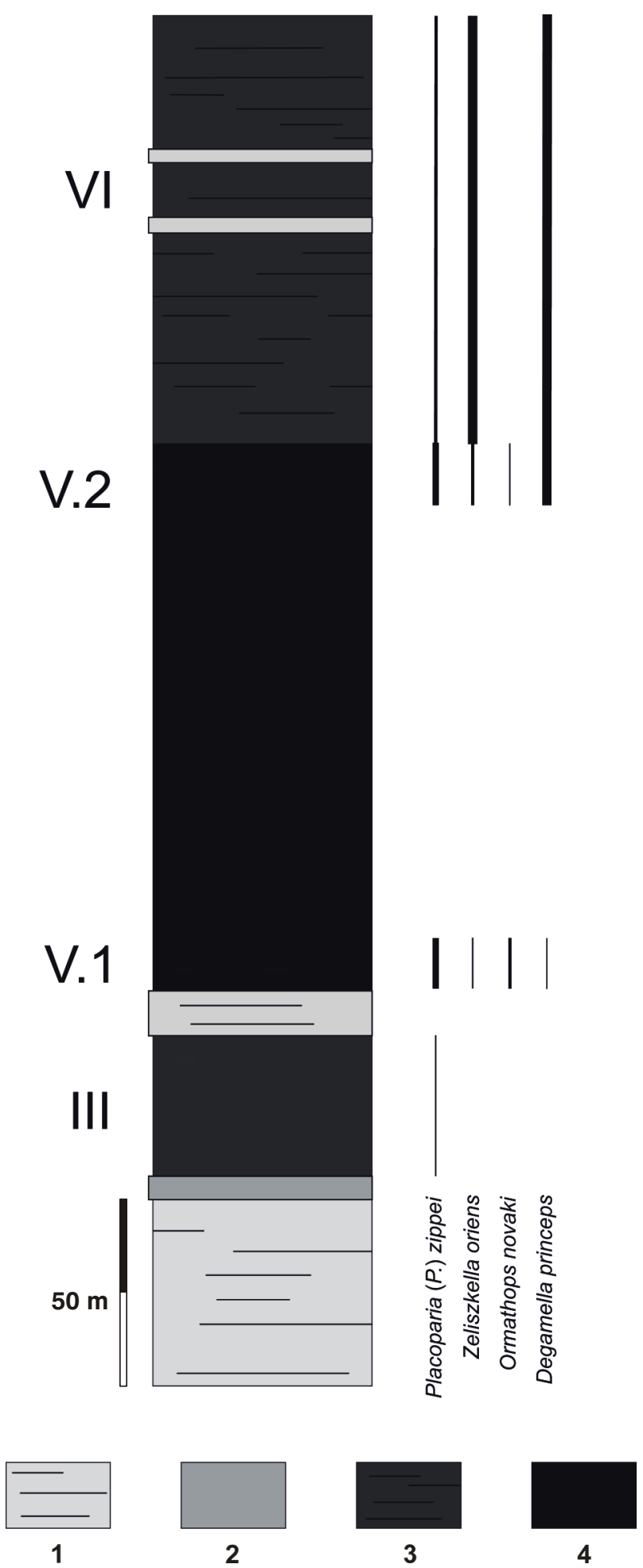

Figure 1. A schematic subdivision of the Džbán water reservoir section with marked ranges and relative abundances of the most important trilobite species forming somewhat different associations in its lower and upper part. 1 - quartz sandstone; 2 - platy quartz sandstone and siltstone; 3 silty shale; 4 - black clayey shale (after Budil 1999a). 
usually with monospecific accumulations of exoskeletal parts: Dindymene plasi, Zbirovia arata, Areia fritschi, Selenopeltis macrophtalma, Dionide jubata and Nobiliasaphus repulsus (partially stored at NM 16/92). Colpocoryphe adisol is represented by a single well preserved specimen (Fig. 2, CGS PB501). Mesopelagic elements are represented by a few Pricyclopyge binodosa longicephala and rare Degamella princeps specimens (NM 16/92). Sessile benthic invertebrates are rare, represented by crinoids Cheirocrinus sp. (disarticulated plates and incomplete thecae) and unidentified columnals; rare conulariids Metaconularia imperialis, rare brachiopods Benignites primulus, monoplacophoran Archinacella sp. and by rare small hyolitids.

Upper part of this sequence, V.2, is separated from the lower, V.1, by about $90 \mathrm{~m}$ thick layer of black shale with rare nodules. No fauna was found in this interlayer.

Interval V.2 consists of black clayey to silty shales, is siltier than in lower units of the section, often outcropping as a muddy residuum containing a few shale fragments but very abundant nodules. It is the most fossiliferous part of the entire sequence at Džbán. Fauna occurs in $3-5 \mathrm{~cm}$ dia. nodules. The fossils are characteristically black colored and are often damaged by weathering.

The V.2 association is dominated by trilobites; all other groups are very rare. Occurrence of complete trilobite specimens is less frequent than in lower parts of the section. The mesopelagic Degamella princeps and the benthic Placoparia (P.) zippei are co-dominant. The dalmanitid trilobites are less frequent, with Zeliszkella oriens more numerous than the rare Ormathops novaki; both usually occurring as rare accumulations of complete or slightly disarticulated specimens (some specimens are most likely exuviae). The harpetid Eoharpes benignensis, the illaenid Ectillaenus benignensis and cyclopygid Pricyclopyge binodosa longicephala are rare. Agnostids are rare, being represented by two specimens of Corrugatagnostus morea, only one pygidium and one enrolled specimen were recovered (CGS PB 1502). Two gastropod species, Sarkanella vokovicensis and Cimbularia klouceki are present but rare. Carapaces of phyllocarid crustacean Caryocaris sp. are abundant but indeterminate due to longitudinal enrolling (see Chlupáč 1970). Brachiopods are less common, being represented by Benignites primulus, Brandysia benigna, and Paterula circina. Conulariids are represented by one poorly preserved specimen of Metaconularia sp. (taxa discussed above are partially stored under cumulative No. NM 16/92)

The easternmost and stratigraphically highest interval of the section, interval VI, possesses several notable differences: the lithology of the shale as well as the shape, size, and lithology of the siliceous nodules. The silty shale is softer, greyish to yellow nodules much smaller, flattened and softer than in the underlying part of the section. The included fossils are often damaged or destroyed by weathering. Despite this, identifiable fossils are abundant. Planktonic or nektobenthic forms are dominant, benthic forms are rarer. Complete specimens of trilobites are uncommon; most frequently found are their cranidia. Degamella princeps and Zeliszkella oriens are co-dominant, Cyclopyge umbonata bohemica and Parabarrandia crassa are infrequent (the latter represented mostly by juvenile specimens), Pricyclopyge binodosa longicephala is rare. Placoparia (P.) zippei is much less frequent than in previously described intervals in the section. Emmrichops planicephalus is rare but in comparison with other localities in the Prague Basin it is abundant here (eight specimens have been found). A few poorly preserved fragments of larger trilobites belonging to Nobiliasaphus repulsus, Parabarrandia crassa and Ectillaenus benignensis are present in the collections. The non-trilobite fauna was represented by a common phyllocarid crustacean Caryocaris sp. (CGS PB 521), and numerous brachiopod specimens attributed to Paterula circina and Rafanoglossa impar (NM 16/92).

\section{DISCUSSION}

Fossil associations of the Dobrotivá Formation were discussed previously by Havlíček (1982), and by Havlíček \& Vaněk (1990). The upper part of the formation and its contact with the overlying Liben Formation has been thoroughly studied by Havlíček \& Vaněk (1996). In their concept of the fossil associations in the Dobrotivá Formation, the Placoparia Trilobite Community (see Havlíček \& Vaněk 1990, 1996) is confined to the lower part of the formation, typically associated with an abundant benthic biota. In their treatment of the rich 
trilobite record in the Middle Ordovician Šárka and Dobrotivá formations Mergl et al. (2008) preferred the name Placoparia Association that they understand as continuing (with the faunal changes often on a species level only) from the underlying Šárka Formation. The trilobites of the Šáka and Dobrotivá formations were assigned to the atheloptic associations and the cyclopygid biofacies of deeper outer shelf by Fatka \& Mergl (2009). Placoparia (P.) zippei, Ormathops novaki, Eoharpes benignensis and Pricyclopyge binodosa longicephala as well as the brachiopod Benignites primulus are typical elements of the Placoparia Association in Dobrotivá Formation (Havlíček \& Vaněk 1990 and Mergl et al. 2008), confined to the lower part of the formation belonging to Hustedograptus teretiusculus Biozone (Havlíček \& Vaněk 1990). In the middle part of the Dobrotivá Formation, the deeper-water trilobite association corresponding to the younger Cryptograptus tricornis Biozone gradually substitutes the typical Placoparia Association. This new association is characterized by dominance of Cyclopyge umbonata bohemica and Zeliszkella oriens; Placoparia (P.) zippei is uncommon. The "lower upper" part of the Dobrotivá Formation (absent at the Džbán section) is considered to present (following Havlíček \& Vaněk 1990, 1996) a deepest-water facies and is characterized by a low diversity Paterula Community sensu Havlíček (1982) with the infrequent benthic trilobite Mytocephala mytoensis and rare cyclopygids Heterocyclopyge nigra, Degamella princeps and Cyclopyge umbonata bohemica (Havlíček \& Vaněk 1990, 1996). In our opinion, this association can reflect rather increasing, spreading dysoxia than the deepening of the basin. The uppermost layers of the Dobrotivá Formation have yet another association dominated by Placoparia (Coplacoparia) borni, frequent Pragolithus praecedens, and sparse non-trilobite benthic fauna with some rare pelagic forms (see Havlíček \& Vaněk 1996 and Mergl et al. 2008).

\section{Degamella princeps-Zeliskella oriens Trilobite Association}

Definition: Trilobite association confined to the lower-middle part of the Dobrotivá Formation characterized by the dominance of the cyclopygid Degamella princeps and dalmanitid Zeliszskella oriens.
Type locality: Džbán water reservoir section, intervals V.2 and VI

Other localities: Praha-Liboc (Veleslavín), see Havlíček \& Vaněk $(1990,1996)$ and Havlíček et al. (1993).

Characterization: Nectobenthic (mostly cyclopygid) trilobites, especially eponymous Degamella princeps dominate. Pricyclopyge binodosa longicephala and Cyclopyge umbonata bohemica are rare. Emmrichops planicephala is also rare but characteristic, the nileid Parabarrandia bohemica is common, agnostoid Corrugatagnostus morea is distinctive. Among benthic forms, the dalmanitid Zeliskella oriens dominate meanwhile the pliomerid Placoparia (P.) zippei is generally infrequent. The illaenids (Ectillaenus benignensis), harpetids (Eoharpes benignensis), asaphids (Nobiliasaphus repulsus) and trinucleoids (Pragolithus praecedens) are rare.

Discussion: Lower part of the section at Džbán (intervals III-V.1) belongs to the Placoparia Association sensu Mergl et al. (2008) and corresponds to the lower part of the Dobrotivá Formation. The association from Džbán is, however, slightly different from the typical Placoparia Association sensu Mergl et al. (2008) and Havlíček \& Vaněk (1990, 1996), known from Malé Př́lepy, Mýto and Strašice. At Džbán, in interval V.1, Ormathops novaki and Pricyclopyge binodosa are not common and Eoharpes benignensis, relatively common at some other localities distant from Džbán, was rare. Brachiopods are not common, Benignites primulus being the dominant taxon. Significant is a rare occurrence of Cheirocrinus sp. Conversely taxa common in the Placoparia Association at other localities, the styloporans Mitrocystites, Mitrocystella, Lagynocystites, and polyplacophoran Helminthochiton equivoca, are missing at Džbán. This depauperate fauna may indicate unfavorable bottom conditions, perhaps dysoxia; this possibility may also explain the near lack of ichnofossils in the Džbán section.

Intervals V.2 and VI contain different (see Fig. 1) associations dominated by Degamella princeps and Zeliszkella oriens. These associations represent here the newly defined local Degamella princeps-Zeliskella oriens Trilobite Association and the outcrop at Džbán is designated it's type locality. Placoparia (P.) zippei is still present but not dominant. Benthic forms are rare and the sessile benthos is missing. 


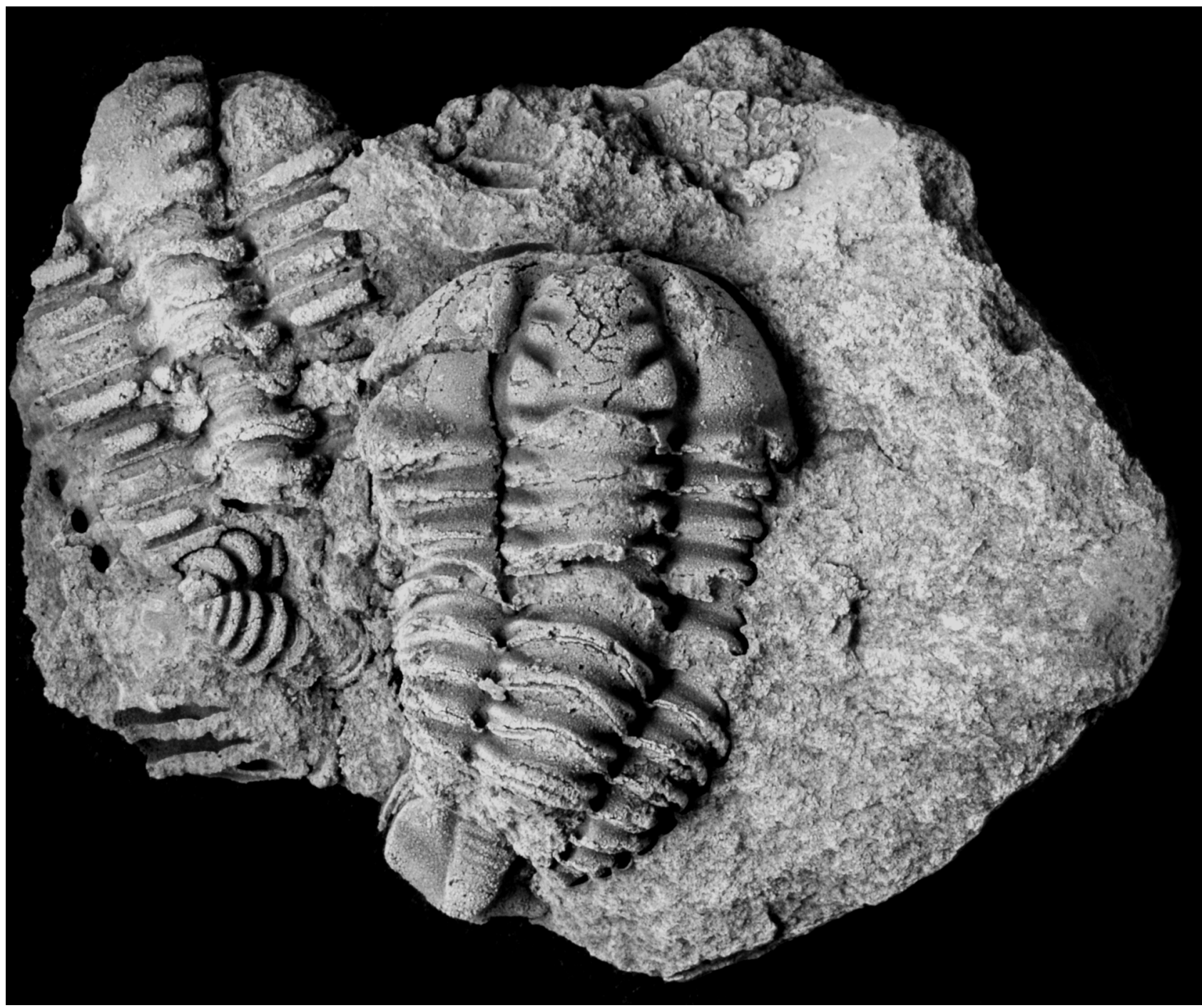

Figure 2. Colpocoryphe adisol, rarely occurring in the part of the section numbered as $V .1$. The sagittal length of partially disarticulated trilobite attains $25 \mathrm{~mm}$; the specimen is housed in the Czech Geological Survey collections under No. PB 501.

The fauna discovered during excavation in the nearby Praha-Liboc in the 1990's (see Havlíček \& Vaněk 1990, 1996; Havlíček et al. 1993 and Peršín $\&$ Budil 2005) can be also affiliated to this newly proposed Degamella princeps-Zeliskella oriens Trilobite Association. This locality at the PrahaLiboc, placed south of possibly synsedimentary (see Peršín and Budil 2009) Š́rka Fault, was correlated by Havlíček \& Vaněk (1996) to the B.A.4. life zone sensu Boucout (1975). Havlíček et al. (1993) and Havlíček \& Vaněk (1996) explicitly state that the association in the supposedly lower part of the Dobrotivá Formation, gathered at Praha-Liboc, represents a different, deeper-water faunal association to compare with other associations at Praha-Vokovice, north of the Prague Fault ("The Liboc-Veleslavín area clearly differs from the Vokovice area, located north of the Š́rka Fault in composition of the benthic and pelagic associations. Dobrotivá Series at Praha-Vokovice has yielded slope associations confined to a lateral transition of the quartzitic sequence into a deeperwater, black shale lithofacies" see Havlíček et al. 1993, p. 79). The "slope association" at PrahaVokovice was affiliated to the B.A.3 life zone by Havlíček \& Vaněk (1996), and was assigned to their Placoparia Trilobite Community. Neither Havlíček et al. (1993) nor Havlíček \& Vaněk 
(1996), however, knew the Džbán section (described later by Budil in 1999), where a superposition of the Placoparia (lower in the section) and the pelagic-dominated, newly defined Degamella princeps-Zeliskella oriens trilobite associations is present. In summa, surface and subsurface excavations at Praha-Liboc exposed black shales of the Dobrotivá Formation with abundant trilobite faunas corresponding well with the newly defined local Degamella princeps-Zeliskella oriens Trilobite Association. The association at Praha-Liboc consists mainly of mesopelagic Degamella princeps and Parabarrandia crassa. The benthic fauna includes Zeliszkella oriens as the dominated taxon; thus it can be correlated with the upper part of the Džbán section. The Praha-Liboc locality produced rare graptolites including Hustedograptus teretiusculus, which indicates that the strata exposed there correspond to the lower part of the Dobrotivá Formation. The relatively common occurrence (nine specimens) of Emmrichops planicephalus would suggest a correlation with the upper part of Džbán section. The agnostid Corrugatagnostus morea is relatively common at Praha-Liboc supporting the correlation with the upper part of the Džbán section. At both Liboc and Džbán, Placoparia (P.) zippei often occurs in monospecific accumulations of nearly complete to complete specimens on some bedding planes, or (at Džbán) in nodules, but it was not the dominant taxon.

Whether the same faunal change from the typical Placoparia to the Degamella-Zeliszkella Association happened also in the other parts of the Prague Basin or if it is confined to the PrahaVokovice area only cannot be decided at current level of knowledge. Future excavations in lower parts of the Dobrotivá Formation may elucidate this question.

\section{CONCLUSIONS}

Džbán locality provides an excellent opportunity to trace the local faunal changes from the lowermost to lower-middle part of the Dobrotivá Formation (with reservation concerning a possible tectonic faulting of the section, see the Introduction). It has recorded a time-dependent environmental change rather than an evolutionarily driven transition from an association dominated by Placoparia to one dominated by mesopelagic forms with abundant Degamella princeps and benthic Zeliszkella oriens. The stratigraphy of the lower part of the Dobrotivá Formation, especially in the NW and NE part of the Prague Basin, is not well exposed and not fully understood. It is not known if the Degamella princeps-Zeliskella oriens Association, defined herein, is a lateral, deeper-water equivalent of the Placoparia Association or if it gradually replaces the later in the lower-middle part of the Dobrotivá Formation. The observations from the Džbán locality support the latter model. A study of the transformation of the benthic-dominated to the pelagic-dominated trilobite associations in the middle part of the Dobrotivá Formation is needed.

\section{ACKNOWLEDGEMENTS}

The contribution was supported by the Czech Geological Survey projects No. 338800 and 343500.

We are very grateful to the reviewers, Dan C. Chaney (Smithsonian Institution, National Museum of Natural History, Washington, DC), Petr Kraft (Charles University, Prague) and Michal Mergl (University of West Bohemia, Pilsen) for their constructive comments, which much improved the manuscript.

\section{REFERENCES}

Boucout, A. J. 1975. Evolution and extinction rate controls. 427 pp. Elsevier, Amsterdam.

Budil, P. 1999a. Nový výchoz dobrotivského souvrství v Praze-Vokovicích (střední ordovik). Journal of the Czech Geological Society 44(1-2), 195-199.

Budil. P. 1999b. A review of the stratigraphic distribution of the family Dalmanitidae Vodges, 1880 in the Ordovician of the Prague Basin (Barrandian, central Bohemia). Acta Universitatis Carolinae, Geologica 43 (1/2), 369-371.

Chlupáč, I. 1970. Phyllocarid crustaceans of the Bohemian Ordovician. Sborník geologických věd, Paleontologie 12, 41-77.

Chlupáč, I., Havlíček, V., Kř́̌̌z, J., Kukal, Z. \& Storch, P. 1998. Palaeozoic of the Barrandien. Czech geological survey, $183 \mathrm{pp}$.

Fatka, O. \& Mergl, M. 2009. The "microcontinent" Perunica: status and story 15 years after conception, 65-102. In Bassett, M. G. (ed) Early Palaeozoic Peri-Gondwanan Terranes: New Insights from Tectonics and Biogeography. 
Geological Society of London, Special Publications $325.37 \mathrm{pp}$.

Havlíček, V. 1982. Ordovician in Bohemia: development of the Prague Basin and its benthic communities. Sborník geologických věd, Geologie 37, 103-136.

Havlíček, V. \&Vaněk, J. 1990. Ordovician invertebrate communities in black-shale lithofacies (Prague Basin, Czechoslovakia). Věstník Ústředního ústavu geologického 65(4), 223-236.

Havlíček, V., Vaněk, J. \& Fatka, O. 1993. Floating algae of the genus Krejciella as probable hosts of epiplanktic organisms (Dobrotivá Series, Ordovician; Prague basin). Journal of the Czech Geological Society 38(1-2), 79-88.

Havlíček, V. \& Vaněk, J. 1996. Dobrotivian/Berounian boundary interval in the Prague Basin with a special emphasis on the deepest part of the trough (Ordovician, Czech Republic). Věstník Českého geologického ústavu 71(3), 225-243.

Mergl, M., Fatka, O. \& Budil, P. 2008. Lower and Middle Ordovician trilobite associations of Perunica: from shoreface endemicity to offshore uniformity (Prague Basin, Czech Republic), 275282. In Rábano, I., Gozalo, R. \& García-Bellido, D. (eds) Advances in trilobite research. Cuadernos del Museo Geominero 9. 7 pp. Instituto Geológico y Minero de España, Madrid.

Peršín, J. \& Budil, P. 2005. Nové poznatky ze šáreckého a dobrotivského souvrství (ordovik, stupeň darriwil) v severozápadní a severní části Prahy. Český kras 35, 26-36.

Šnajdr, M. 1987. New Bohemian Ordovician Dalmanitidae and Calmonidae (Trilobita). Věstník ústředního ústavu geologického 65(5), 271277. 